Article

\title{
Sustainable Family Life and Child Welfare: A Conceptual Framework
}

\author{
Juha Hämäläinen ${ }^{1,2,3, * \mathbb{C}}$, Kaisa Pihlainen ${ }^{4} \mathbb{D}$ and Riitta Vornanen ${ }^{1}$ \\ 1 Faculty of Social Sciences and Business Studies, University of Eastern Finland, 70211 Kuopio, Finland; \\ riitta.h.vornanen@uef.fi \\ 2 Faculty of Social Studies, University of Ostrava, 70200 Ostrava, Czech Republic \\ 3 School of Social Development and Public Policy, Fudan University, Shanghai 200433, China \\ 4 Philosophical Faculty, University of Eastern Finland, 80100 Joensuu, Finland; kaisa.pihlainen@uef.fi \\ * Correspondence: juha.hamalainen@uef.fi; Tel.: +358-50-593-9415
}

Received: 30 September 2020; Accepted: 29 October 2020; Published: 2 November 2020

\begin{abstract}
Although there have been developments in family and child welfare services, these have not been prioritized from a sustainability perspective. This article aims to provide a framework for supporting sustainable provisions for family and child welfare. We demonstrate how the need for a socially sustainable stance on family and child welfare arises from the recognition of global changes that constantly influence families as well as children's rights, which ground child- and family-centered actions. The conceptual framework includes three overarching dimensions and four levels of actors that provide a body for 16 conceptual entities in providing socially sustainable family and child welfare. The analysis showed that functional child welfare and family policies, systems, and practices appear essential elements, even necessary preconditions, of sustainability and sustainable development in general. Leaning on the concept of children's rights, we conclude that the idea of child welfare promises citizens that society has committed to promoting all children's wellbeing. Implementation of this requires a shared understanding that the conceptual framework provided in this paper urges to actualize.
\end{abstract}

Keywords: sustainability; family life; child welfare; children's rights

\section{Introduction}

A sustainability perspective focusing on family life has not been given precedence. Most often, sustainability has been linked with families from the perspective of adopting an ecological way of living or with children from the viewpoint of educating about an eco-sustainable lifestyle [1]. It has also beneficially focused on preventing poverty among families and children. From the perspective of sustainability, the questions are how to support families with children, make such investments in child and family policy so that families feel secure, and ensure children's resources for the future.

Among family policies, there are reasons for regarding children's rights and child welfare policies as an essential element in the concept of sustainable development. In principle, issues of child welfare and family policy are located primarily in the social dimension of the comprehensive framework of sustainable development. However, as the social, economic, and environmental aspects of sustainable development intertwine, there is a good reason for discussing child welfare from a broader point of view, within a comprehensive conception of sustainability.

The United Nations Sustainable Development Goals (SDG) include 35 child-focused indicators, and children are mentioned in many of the 169 targets [2,3]. Despite the existing sustainability goals aimed at children's wellbeing and health, there is a need for more integrated focus on sustainability and equity of children rooted in the Convention on the Rights of the Child and to evaluate the progress of 
sustainability from the perspective of children [4-6]. A children's rights perspective can be strengthened by generating knowledge on child development in diverse contexts, developing measurement and monitoring, building capacity and infrastructures in different countries [5], and promoting equity and realizing the rights of children so that they are able to lead fulfilling lives [7].

In this article, the word social sustainability is used when focusing on sustainability in the context of child welfare. Social sustainability can be linked to the alleviation of poverty and promoting participation, inclusion, cultural identity, institutional stability, and social cohesion. These goals can be promoted by social policy and human rights [8]. There is no clear consensus on the concept of social sustainability. It can be related to basic needs and equity, quality of life, social capital, social cohesion, integration and diversity, sense of place, and education [9]. In this article, our purpose is to discuss the concept of child welfare as an element of sustainable social development and provide a conceptual framework for the provision of support for socially sustainable family and child welfare.

The need for a socially sustainable view in family and child welfare arises from the recognition of global changes that constantly influence families. The digitalization of work, public services, and leisure activities provide many families with new opportunities to ease and expand their daily lives, such as supporting distance work, facilitating the use of public services regardless of the location, and providing a venue for social interaction, entertainment, and hobbies. Simultaneously, digitalization may increase the inequality of the families regarding their access and ways to use digital devices. Conflicts or natural disasters force millions of families to migrate and to live in temporary settings. Most recently, the COVID-19 pandemic isolated families at home and restricted social interaction mostly to online communication. Constant changes challenge the socially sustainable way to implement family and child welfare.

Sustainable family and child welfare requires the recognition of values that consciously and unconsciously affect our practices, the recognition of interdependence and that family and child welfare practices take place in a specific time and place and affect the other practices and environment reciprocally, and the recognition of resilience that is needed and that can be strengthened at an individual and group level to accommodate constant changes in a sustainable way.

\section{Children's Rights as a Starting Point for Family and Child Welfare}

In this chapter, we focus on the Convention on the Rights of the Child. Although the convention and its ratification and implementation have been widely studied, the sustainability perspective has been addressed mainly for the most drastic questions of child labor in developing countries. We look of the convention and the principles of protection, provision, and participation and interpret those from the broad perspective of sustainability to build a more general framework for child and family welfare.

\subsection{The Convention of the Rights of the Child}

The history of the philosophy and policies of children's rights is not a linear and progressive process but "a complex interplay of national, regional, and transnational influences and controversies" in which "the cause of the rights of the child mobilized international public opinion, leading intergovernmental organizations to adopt specific legal instruments on the issue" [10]. The UN Convention on the Rights of the Child [11] is regarded as a continuum of previous legal instruments: The Declaration of Geneva, 1924 [12], and the UN Declaration of the Rights of the Child, 1959 [13].

As with the previous international children's right documents, the UN Convention on the Rights of the Child (CRC) [11] provides a foundation for international cooperation in the field of child policies and child welfare, aiming to improve children's living conditions by tackling child poverty, child labor, and corresponding circumstances as well as promoting opportunities for sufficient care, adequate education, and health [14]. "Every child has rights, whatever their ethnicity, gender, religion, language, abilities, or any other status" [15].

Even though the Convention on the Rights of the Child was launched more than 30 years ago and was the most widely-ratified international human rights treaty in history, millions of children 
across the world are still being prohibited their rights $[2,16]$. Therefore, identifying the shortage in progress, the sustainable development goals coordinate global efforts to reach "those left furthest behind first" [17]. In addition, there are conceptual and ethical tensions in interpreting, legitimizing, and implementing the rights of the child. The universal right to education, for example, can be discussed from the point of view of children's rights, parent's rights, or even citizen's rights and justified by referring to different social, ethical, and political values such as freedom, equality, justice, and democracy [18]. Education concerns protection, provision, and participation of the rights of the child.

Historically children's rights and women's rights interrelate and have developed interdependently [19]. As to the general human rights, the rights of the child have developed from social rights, especially the right for protection, towards rights for personal freedom and self-determination, while the general human rights have developed from right for freedom as civil rights towards expanding social rights. There are reasons to distinguish "social rights" from "private autonomy rights" of the child [18]. Likewise, women's rights and the rights of the child are regarded and conceptualized as a unique field and a kind of application of general human rights.

As a hypernym for wide-ranging interdisciplinary research, policymaking, and professional activities, the concept of children's rights is a key concept of modern child and family policies, and child welfare is a crucial element of modern welfare systems, even modern judicial and political systems. Accordingly, there is a diverse academic debate around children's rights and the concept of child welfare in the community of scholars [20]. Nonetheless, scholars agree that the Convention on the Rights of the Child has principles of protection, provision, and participation. These principles have been used widely in research and in implementing the convention.

Principles and rights are somehow universal, but rights are realized in specific contexts. The Convention on the Rights of the Child offers a basis for a sustainable life for children. The convention targets many levels where actions and support for children's protection, participation, and provision should occur. The Convention on the Rights of the Child balances the rights of children to the level of their families and the state and emphasizes the role and support of families and, on the other hand, the circumstances when the state has to intervene in family life if there are concerns about protection [21]. Therefore, there is a dependence between the child, family, and state, but there are differences in how child protection is regulated in different child welfare systems and policies [22,23].

\subsection{Principles of Protection, Provision, and Participation in Children's Rights}

The Convention on the Rights of the Child gives values and principles for thinking sustainable life for children and families. It also offers the possibility to focus on different levels of protection, provision, and participation from a social sustainability perspective.

Protection, as a principle of the rights of the child, means protecting children from risks as well as guaranteeing their health and development. We can also think of it as the universal principle of protecting childhood as a life phase in different societies. This perspective has been strengthened during the 21 centuries. Social sustainability, in its profound meaning, is contained in the safe growing conditions of children. The current discussions on ecological sustainability focus on environmental issues, climate change, or fighting for diseases and poverty. Family is a core context of children's health and wellbeing and parent's ability to take of children. Therefore, social sustainability means protection of children's health and safe development as well as childhood as a life phase. In promoting children's health and development, there is a need to focus more on early child development [4] in order to build knowledge of children at risk in different contexts [5] and understand how the health of the child is defined [7].

Provision, as a principle, means children's right to have their share of resources. In a family environment, this means that the family can take care of housing, healthy food, education, and hobbies. Institutions around the family, such as schools, may support provision by offering school meals. Provision, on a societal level, is related to all policies concerning economy, social policy, and education 
policy as well as the social welfare system and its capabilities to support families and children. Combined with the protection principle, provision may also mean that a child is not neglected. Neglect may be emotional, nutritional, physical, medical, educational, or a lack of supervision and guidance [24] and may be related to parenting but also the deficiencies in a social environment [25].

Provision of resources and care does not always depend on the willingness of parents, and in those cases, it can be more related to poverty issues than the neglect of children's needs. In this case, social sustainability as a provision means children's share of resources during childhood, e.g., alleviating child poverty, food, housing, education, child and family policy, education policy, and child welfare in supporting households. Social sustainability in provision also means the share of resources between generations, countries, and nations. These resources are not just economic but also environmental resources and sustainable climate for living.

Participation, as a principle, means a child's right to participate according to his/her capabilities, age, and development. "Right to participate" is related to a child's daily environment, including family, school/day care, and other factors within the environment. The institutions, such as early childhood education and school, and the peer-groups create both official and unofficial chances to participate. Children's participation has been theorized from many perspectives in research [26] and in the context of child welfare, where a child has to be heard in processes concerning her/his own life and future. Participation takes place in a family as well as in all other institutions and society. Social sustainability in participation refers to children's right to develop their agency according to their age and abilities during childhood and right to have a family and educational environment that supports their learning to influence on their own life and participate at home, other institutions, and gradually on society as citizens with all social, educational, economic, and political rights. Children's participation can be just a phrase unless it is meaningful for the children and is effective in leading to sustainable changes [27].

All in all, social sustainability in children's rights concerns not only the current lives of families and children, but also ways to support future generations. In definitions of social sustainability, the ability of a community to develop a good and healthy society for the current members is linked to the future perspective for a sustainable life for future generations [28,29]. Therefore, sustainable child welfare for protection, provision, and participation can be viewed from current and future dimensions and examined separately, even though in child welfare, these topics are closely interconnected. For example, protection and participation are related to significant people in a child's life and family, allowing a child to experience belongingness and love. "Provision" means securing the resources for nutrition and a home as a shelter from the outside world. A child's share of resources can be in the shadow of other issues if we understand it solely as material resources for basic living. "Provision" also means resources for development and learning, and together with participation, it expands the chances for self-actualization, peer-relationships and community-belonging.

All these principles are essential to child welfare, where the principle of protection has been dominant. The principle of protection can be implemented in a minimal way when a society intervenes in children's lives only if a child's health is at serious risk. In developed child welfare systems, child welfare and protection are linked to child and family policies, and also address the needs for provision and participation.

\subsection{Philosophy of Sustainability and the Rights of the Child}

The global 2030 Agenda for Sustainable Development for social, economic, and environmental dimensions includes 17 goals with 169 concrete targets and 232 indicators, 35 of which are targeted at children. UNICEF has committed to promoting the goals for children's wellbeing so that every child survives and thrives, learns, is protected from violence and exploitation, lives in a safe and clean environment, and has a fair chance in life [30]. The 2030 Agenda is clearly intertwined with the Convention on the Rights of the Child and the principles of protection, provision, and participation.Sustainability is a global, international, and national level challenge at the same time. At the national level, welfare systems and other infrastructures are needed to implement the rights of 
children, and a lack of infrastructure or weak institutions may lead to a minimum level of protection. Sustainability is also linked with justice between nations and the sharing of resources available for children and families. In this meaning, children have to be protected from violence [31] and provided with rights for education [32] and proper living conditions.

Children are vulnerable to global issues such as climate change, migration, health problems such as pandemics, poverty, human trafficking, and the weak status of minority populations. The global inequality and the indivisible problems together are in the core challenges for sustainability. Challenges can be indivisible challenges and cannot be solved by single countries.

The philosophy of social sustainability deals with equality and rights, and for children, the Convention on the Rights of the Child has established the goals with other international agreements and international and national policy procedures. Eizenberg and Jabareen [29] emphasize justice as a central part of the social sustainability and focus on three dimensions: redistributive, recognition, and participation. Redistribution means distributive justice, which guarantees the adequate standards of living and the right to clean water and related resources. Recognition means rights for vulnerable groups and the possibility to have an equal status in society, as well as having a voice and the possibility to influence society, thereby opposing discrimination. They also address the importance of participation, which is related to the involvement and distribution of resources. Intergenerational and intragenerational justices mean the fair share of resources among people at present. Implementation of children's rights globally as well as on a national level is intertwined with the issues of justice.

\section{Dimensions and Levels of Sustainable Family and Child Welfare}

In this chapter, we ground the formulation of a conceptual framework for sustainable family and child welfare in two viewpoints. Firstly, we describe the levels of actors that exist in the provision of sustainable family and child welfare. Secondly, we examine these levels from three overarching dimensions, i.e., values and practices, interdependence, and resiliency. The purpose of this examination is to shed light on the multifaceted and changing phenomenon of family and child welfare as well as to structure the discussion on social sustainability regarding family and child welfare.

\subsection{Levels of Sustainable Family and Child Welfare}

A typical way to describe a child's growth environment is an ecological model that refers to the interdependences of subjects in their environment. These models recognize that individuals are active in interaction, and interactions between the environment and individuals are reciprocal. The model presented in this paper refers to Bronfenbrenner's [33] ecological systems theory, including nested circles of actors. Levels of actors in this paper include child, family, society, and global (Figure 1). The ecological model has been used in sustainability research as a child-centered approach to investigate the sustainable development goals. In [3], SDGs are located in the outer circles and supposed to be realized as child outcomes that are located in the middle. We use the model in a simple form to illustrate the relatedness of children's wellbeing and health to family, society, and global issues. We have chosen here the three dimensions: (1) values and practices, (2) interdependence, and (3) resiliency, which are crucial in implementing sustainable family and child welfare on the child, family, society, and global levels.

Children are in the core of developing and implementing family and child welfare (Figure 1). The purpose is to put children's rights into practice and support children's growth and development. The closest people of the child are his/her family members, referring mostly to parents, but also including siblings, grandparents, and other people that closely interact with the child. Societies, in turn, support families in upbringing their children by laws and regulations as well as providing direct or indirect support for families. Broadly, a global scale, such as international declarations and global challenges and changes, affects the families through the societies' practices.

We recognize that these four levels (i.e., child, family, society, and global) interact, co-exist, and influence reciprocally in all directions. This refers to ecocultural theory [34], which emphasizes the 
influence of the environment on children's and families' lives. In practice, we can influence the growth and development of the child by cultivating the environment. Through ecocultural theory, we can also recognize the importance of culture, including beliefs, values, and practices that are crucial in organizing and implementing family and child welfare.

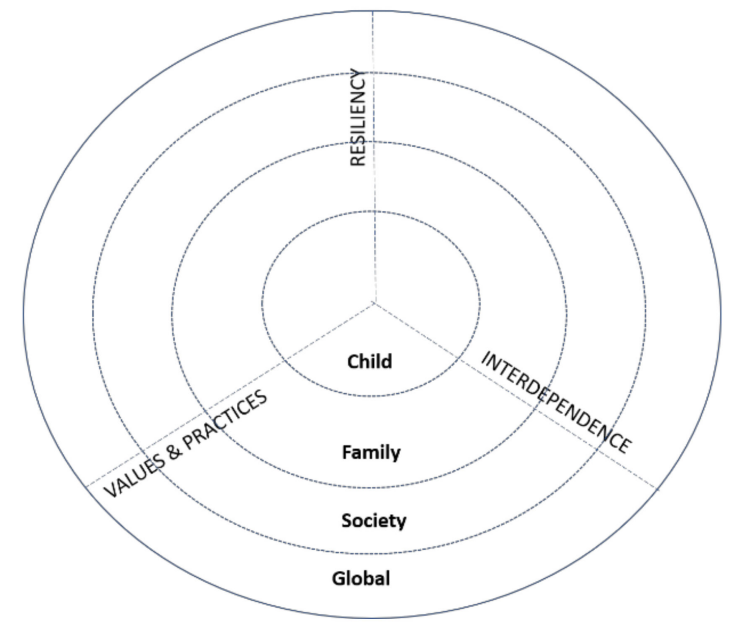

Figure 1. Dimensions and levels of sustainable family and child welfare.

\subsection{Dimensions of Sustainable Family and Child Welfare}

In this chapter, we investigate sustainable family and child welfare from three viewpoints. Firstly, socially sustainable family and child welfare practices are based on values that individuals and societies reflect in their actions. Current values lean on recognizing childhood as an individual phase of life and children as experts of childhood. In a family level, families' individuality, e.g., culture, religion, and habits, are valued by rights and regulations. Simultaneously, families have a right to receive support, and family interventions are legitimized. Secondly, interdependence within the various stakeholders and phenomena is omnipresent, and these levels mostly do not exist without a connection to others. These connections are described from three viewpoints, including the global trends, the connection between the children's rights and implementation of family and child welfare services, and the intersection between social, economic, and environmental sustainability in family and child welfare. Thirdly, the aspect of resilience is highlighted in understanding how values, practices, and the interdependency of stakeholders influence and balance continually changing circumstances in a socially sustainable way.

\subsubsection{Values and Practices in Sustainable Family and Child Welfare}

Values and practices will be discussed from three viewpoints. We start by describing cultural perspectives on values and practices. Then we discuss national child's welfare in an international context. We end the chapter by reflecting on the values and practices of the modern family and child welfare.

\subsubsection{Interdependence in Sustainable Family and Child Welfare}

As we have presented earlier, sustainable family and child welfare is a multifaceted, multi-layered phenomenon that interacts with and is dependent on various factors on a children's, families', societies', and global level. In this chapter, we concentrate on three overarching topics: How global trends influence societies and individuals, how children's rights influence provision of family and child welfare, and how economic and environmental aspects influence family and child welfare. 


\subsubsection{Resiliency in Sustainable Family and Child Welfare}

In this chapter, we will introduce resiliency as a concept applied to families and communities. We emphasize both family resiliency and community resiliency as essential characters for a socially sustainable society. Family resiliency and community resiliency enhance the secure, growing environment for a child.

\subsection{Cultural Perspectives on Values and Practices}

The concept of childhood varies between cultural traditions and contexts. Anthropological perspectives on childhood provide information about different concepts of childhood in relation to diverse cultural patterns [35]. Explaining the special features of national child welfare systems requires adequate sensitivity to cultural traditions, especially the concepts of childhood, parenthood, and the family. In any case, child welfare systems are principally legal and political establishments, and, as such, each national system of child welfare embodies the same country-specific value and norm systems as the nation societal structure otherwise [36]. Accordingly, as legal and political establishments, child welfare systems instantiate ethical ideas and principles with respect to political will.

From the point of view of the concept of childhood, it has been stated that the concepts of children's rights and children's wellbeing, despite having different trajectories, share common ground and that the concept of children's participation provides a basis for the development of a paradigm to shift "from children and emerging citizens to children as experts in the field of childhood" [37] (p. 68). In practice, this shift is reflected by noticing children as active participants [38] who can point out their actual views [39]. Many international policy documents provide guidance for evaluating children's participation in legislation, policy, and practice [40]. These help to constitute the ideological basis for valuing the voices of children with respect to age and development and considering them in decision-making processes concerning children.

\subsection{National Child's Welfare and Child Policy in an International Context}

As integrated parts of national welfare systems, child welfare policies consist of policy measures to promote children's wellbeing with respect to contextual, relational, and conditional social questions of childhood, policies, and legislation [41]. Connecting with the ideology of children's rights, they apply not only to national welfare systems but also to legal systems, especially child and family law, as legislation equally reflects cultural, political, social, and economic aspects of social order [42]. Similarly, comparative research on family policy and child protection requires concepts and methods from both comparative social policy and comparative law.

Various goals and systems related to population growth and well-being, as well as other variations in concepts, goals, and means in national family policies over time and across countries, make cross-national comparisons difficult [43]. Understandably, this difficulty also applies to the comparison of child welfare systems and interpretations of children's rights in different countries [23]. However, there is a wealth of comparative social policy research over several decades that sheds light on the country-specific features and developments of family policy and also helps to understand country-specific child welfare practices in the light of family policy systems with respect to nation-specific economic, social, cultural, and political factors.

Child protection policy, the implementation of children's rights, and family policy systems are nested entities in the social order. With regard to the implementation of child protection, family policy systems in particular play a key role. Just as country-specific child protection policies and systems are subsystems of national social policy machinery, they reflect the same specificities as national social systems as a whole [44]. International cooperation for the development of children's and women's rights has contributed to the development of national family policy systems, in particular through 
the promotion of human rights $[45,46]$. Accordingly, family support is considered to be a right of the child [47].

Human rights and children's rights [48,49] declare and embrace the diversity and rights of families and children. Parallel to that, modern societies have established multifarious systems of benefits and services for protecting and supporting children and families amid increasing insecurity. Traditionally child welfare is to consist of three main aspects: education, health care, and judicial protection. These aspects are still focal fields of child welfare policies and services, although child welfare policies and systems vary significantly from country to country.

It is of vital importance "to focus on the complex issues requiring a holistic prevention-based intersectional and interdisciplinary approach to child protection globally, a platform for professionals to join in developing and strengthening practical, effective child protection prevention, systems and services", which has been often emphasized regarding the need to protect children against maltreatment [50] (p. 988). Children at risk are a heterogeneous population with respect to kinds of risks and needs. Even children with disabilities are a very heterogeneous multitude in need of diverse professional expertise and specialization including the multifaceted organization of services [51-53]. International declarations and conventions oblige the countries to support the human rights of the people with disabilities [54].

\subsection{Values and Practices of Modern Child and Family Welfare}

Several modern societies value family- and child-centered services. This means that several professionals and institutions are involved in the mission of child welfare with respect to the rights of the child, and services-such as schools—are provided close to a family and in their daily environments. An excellent example of such a specific professional activity is the role of school psychologists and school social workers in accessing and supporting "progress towards the aspiration that children have equitable access to services that promote healthy development regardless of parental limitations" [55] (p. 29), as well as implementing the rights of the child in many other ways in school settings [56-59]. Corresponding examples of service provision for children and families regarding children's rights could be shown in all professional fields dealing with children and families, such as early childhood education, youth work, and the wide range of social and health care services.

Modern child welfare entails both risk prevention-in the sense of largely influencing the living conditions of the child population in society and child- and family-specific protection-and support for children and families at risk of particular problems causing a need for special support. Child- and family-specific support requires special professional know-how and skills. Additionally, an extraordinary aspect of modern child welfare is the system of taking the child into care. This form of child welfare is regulated differently in national legislations. The key point, in any case, is to protect the child against detrimental conditions at home threatening her health and development, such as maltreatment and neglect. Principally, the fundamental qualification of taking the child into care is the principle of the best interest of the child. This principle is an essential guide of modern child welfare thoroughly.

However, family life and relationships in families are more complicated than legal and social-political frameworks of family policies and child welfare with respect to the rights of the child. For example, studies on caring for children show that care given to children in family care arrangement should not be discussed only in terms of vulnerability and agency regarding specific cultural, familial, socioeconomic, and structural factors, because "the needs of children and young people can hardly be separated from the needs of others who are important to them as family members", and therefore there is a need for "an understanding of reciprocity, interactivity, and negotiation of rights and responsibilities between parents and child" [60] (p. 455). It has been stated that it is inappropriate to discuss the relationship between parents and children as an issue of rights [61]. Universal conceptions of the rights of the child might be hard to reconcile with the uniquity of family. 


\subsection{Influence of Global Trends to Societies and Individuals}

Worldwide, individual societies are shaped by global economic, social, and cultural megatrends. Global changes influence macrosocial structures of individual societies, affecting people's living conditions and preconditions of everyday life at a microsocial level, and are expressed in diverse ways. There is much literature explaining the influence of global trends on individual societies as well as of the consequences of social change to a microsocial domain, including family life, parenting, and childhood [62-64]. In light of research, the consequences of the change of working life to family life are somewhat apparent. However, there is relatively little debate on the consequences of social change to the families and child welfare around the concept of sustainability.

The evidence suggests that the circumstances and changes at a societal level, such as in working, housing, and living conditions, are not often sufficiently child- and family-friendly. Following the ICT revolution, digitalization, and informational intensity, work has changed widely to be increasingly more cognitively demanding. In consequence of automation, work is increasingly about control and oversight of production processes. Accordingly, the employment market has changed: there are more and more available high-level expertise jobs, which require professional skills and are based on a relatively high level of education. Moreover, successful performances need constant updating of professional knowledge and skills. In this sense, modern societies are characterized as information-intense high-tech societies, in which job markets and working life require progressively higher-level professional know-how based on high-quality training. The demanding job may not only take time from parent-child togetherness, but also undermine parents' capacity for adequate emotional interaction with children. Parents may have a difficult balancing act to perform between family responsibilities and the pressures of their working life. Consequently, children are particularly at risk of neglect and in need of protection against inadequate care, upbringing, and safeguarding.

The modern job market is not only professionally demanding but increasingly insecure, too. Consequently, families with children cannot plan their future in the very long term. The insecurity may manifest itself as both economic and psychosocial problems. In this sense, social change has significant consequences for children through increasing insecurity of family life. At worst, the mental stress of parents caused by insecurity may erupt as violent behaviour in the sense of family violence. As the high-tech society is essentially an information society, it is necessarily a learning society too. As to the influence on children, the modern society requires a successful learning career based on cognitive performance, tending to favor talented individuals and, accordingly, threatening to exclude those who have learning difficulties and behavioral problems. Thus, social change is shaping children's everyday life and preconditions of life course not only through the family, but also through the school.

As we know, the position of poorly educated people is the most insecure in the modern job market. There is evidence that the social vulnerability of children and young people is essentially linked to their scholastic career. We also know that families play an important supporting role in children's school career. Accordingly, child and youth policy aiming to prevent and alleviate the risk of social exclusion and weak position in the job market covers both family support and school education particularly.

Apart from the challenges of the external circumstances, the rapid social and cultural change complicates the role of parenting. There is a need to consider both external circumstances and personal capacities of families to provide adequate care and upbringing for children. The personal causal factors of inadequate parenting and the need for support may mainly concern the lack of relevant knowledge, emotional exhaustion, and disinclination to fulfil parental duties. All these deficits require different kinds of interventions and support. After all, it is vital to see the immense significance of external circumstances in light of the characteristics of rapidly changing modern society.

\subsection{Influence of Children's Rights on the Provision of Family and Child Welfare}

In many Western countries, child welfare has developed from private charity and local arrangements arising in the 18th century to provide children with "a minimum level of subsistence and religious upbringing" to "increasing state responsibility for children" [65] (p. 26). In general, child 
welfare has diversified as a system of knowledge, methods, professional expertise, and disciplines. Modern child welfare is a developed multidisciplinary and legal establishment, manifesting itself in both the national and international context.

Historically, national child welfare systems have developed in close connection to the development of the international conception of children's rights $[14,66]$. Correspondingly, the philosophy of children's rights provides a conceptual framework for national child welfare policies and legislation systems today. Along with the development of children's rights and child welfare policies, child law has become a new branch of jurisprudence including the aspects national and international law of child [67]. Correspondingly, cross-national comparative research of child and family policies has developed along with international political cooperation [68]. There is both academic and political interest in such information based on comparative research. Although children's rights are universal human rights, the interpretations and implementations vary significantly between individual countries. It has been recommended, "to understand the rights legislation holistically, and to be sensitive to cultural context" [35] (p. 110). This may be a relevant perspective for discussing children's rights with respect to sustainability policies as well as a piece of fair advice for the development of international cooperative programs.

The human rights of children have been discussed from a socio-ecological perspective, paying attention, for example, to definition, risk, and opportunity in different system levels [69]. In principle, the rights of the child are universal rights of every individual child. However, there are various attempts to safeguard and promote children's rights both at microsocial and macrosocial contexts. The concept of children's rights requires overall political and professional operations at all system levels.

One prominent example of children's rights is the social and educational exclusion that threatens desirable sustainable development of children and young people. As education is a critical factor of modern information-intensive high-tech society, the implementation of children's rights is closely connected to national educational policies [70]. The right to an education is seen as a fundamental right of the child, as a crucial precondition for appropriate human development [18]. In modern learning society, the human aspect of education may become overshadowed by economic, political, and corresponding external motives. In any case, the right to education as a human right unconditionally concerns every human being and connects national child welfare systems to educational policies. However, educational exclusion in the sense of dropping out of school is a critical factor in social exclusion in modern society, causing potential long-term unemployment in modern society's job market. Plenty of social and pedagogical programs have been developed to prevent and alleviate educational exclusion [71]. Social exclusion of children and young people may not only encumber their economic development, but it may also be a threat to sustainable political development by alienating people from active citizenship.

Children's rights have been regarded as a framework for eliminating social exclusion both in a narrow sense-focusing on educational issues and anti-poverty programs-and in a wider perspective, regarding children's rights as an instrument for the redistribution of resources and an integrated part of public policy in entirety [72]. As to the complexity of modern society, it is reasonable to regard the philosophy of children's rights as a fundamental element at the heart of the whole structure of public policy aiming to guarantee conditions for sustainable development. Additionally, as a unilateral framework for child welfare, the implementation policies of children's rights should be discussed with respect to the diverse economic, social, political, and cultural circumstances [73]. There are many common elements to be considered. For example, child poverty is seen as a critical factor of children's school education "across the world" [74].

\subsection{Economic and Environmental Aspects of Family and Child Welfare}

Apart from the proper fields of child and family policies, the aspect of family life is often considered in several fields of public policies, such as housing, employment, and education policies. In general, family policies attend to provide welfare for families with children by social a political means; this is to 
say, by employing social benefits and services. Traditionally, family policy has aimed at the reduction of child poverty, promotion of the birth rate, and reduction of income differences by means of income transfer for the benefit of families with children. As the family is regarded as the fundamental institution of society, family policies aim to create social stability and sustainability by providing families with economic conditions needed to fulfil their function appropriately. Financial and mental support for families with children through income transfers, social benefits, and family-oriented services is a fundamental element in any developed welfare system. Over the last five decades, the family policy systems of developed countries have become increasingly diverse and layered into national income transfer and welfare service systems [75]. Public childcare expansion has been "the most remarkable family policy development" [76] (p. 2) and "the most recent and most rapidly expanding component of the family policy package" [77] (p. 21), which has sought to mitigate the social risks of modern society while promoting economic policy efforts by enabling women to participate in working life.

Income transfers and welfare services are two key instruments of family policies. The aspect of welfare services consists of various facilities. The efforts to guarantee adequate living conditions for children is the core element of the family services. This is understandable, because parents' mental problems, substance abuse, violent demeanor, cruelty, immorality, and corresponding behavioural disorders jeopardize children's wellbeing and development as well as cause a need for protection. As a social system, child welfare attends to fulfil several functions to protect and support children and families. Historically the core task of child welfare was to protect children against abuse and neglect. In addition, child welfare has been seen as an instrument against the consequences of adverse living conditions such as poverty, unhealthy living environments, orphanhood, and corresponding hazardous circumstances threatening decent moral, emotional, and intellectual development.

Apart from economic issues, environmental sustainability affects social sustainability in family and child welfare. Climate change, including rising temperatures, sea levels, and carbon dioxide levels, as well as extreme weather conditions, affects children the most [78]. Children's vulnerability refers to children's size, physiology, and behaviour [79] that environmental issues produce. Environmental issues and risks combine with other vulnerability factors, such as poverty, violence, and migration, which multiplies the adverse effects for children, especially if the protective factors are lacking. The perspective of children is often missing or undervalued in scientific debate and policy procedures in tackling the environmental issues [80].

Environmental sustainability from the perspective of family and child welfare is a current topic that requires immediate action. However, this topic may be in the shadow of the drastic questions of climate change. Parallel to that, the current issue is to consider the versatile generational perspectives for environmental sustainability. Although social sustainability can be addressed in its own right [3], family and child welfare incorporate the social aspects for environmental sustainability.

\subsection{The Concept of Family Resiliency and Sustainability}

Children's rights are globally addressed by the Convention on the Rights of the Child, ratified by almost all countries. The profound idea of children as subjects with their own rights is already implemented in legislation in many countries. Even if a child has the status of a legal subject and extensive rights to participation, a child needs protection from adults. In this task of protection, adults have a significant role both in institutions of early education and the family.

The wellbeing of a child depends on the community and the consciousness and capabilities of adults to carry out the caring task. Family is a kind of shelter for a child to grow, and the role of parents is to support the child according to her/his age and development. Parental stress can heighten the parents' capability in their caring task. Prolonged stress may lead to a situation in which parents are less available for the children and declining psychological accessibility for children at home [81] (p. 73).

Family resilience, as a concept, can be reflected from the point of view of sustainability. Family resilience is an effort to balance and reach continuity in family life. Family resilience shifts the 
focus from individual family members to the family as a unit [82]. When family demands exceed the capabilities, for example, during family crises, there can be imbalance and disruptiveness in a family.

A crisis can lead to discontinuity in family patterns, but also, imbalance may be related to the disruption of routines. Families may have different methods of trying to balance the situation, doing so by increasing capabilities, reducing the demands, and/or finding new meaning, as well as engaging in processes that lead to better coping or adaptation, moreover, by increasing vulnerability in the family [83]. The impact and consequences of family life and family members may vary. According to Walsh [82], it is essential to focus on how family members handle the situation, to understand the immediate reactions as well as long term strategies with different adaptational pathways.

Sustainability in family life may mean a family's capacity to cope with everyday hassles and find the routines that support continuity in family life. These routines can be concrete schedules for everyday meals or going to bed in the evening. Routines sustain continuity and security in family life. Routines may be linked to a common understanding of parenting tasks, shift between work and rest, or communicating and upbringing patterns. In resilience research, these are known as key processes in family resilience [82] or resilient family prominent and recovery factors [84] (p. 38). Key processes may be such as belief systems, organizational patterns, mutual support, collaboration and resources, and communication and problem-solving [82]. Resilience factors are a similar type of list of issues that sustain family life, such as family time, shared recreation, support networks, and routines and rituals [84].

\subsection{Community and Family Resiliency}

Family is a part of the community, and the link between family resiliency and the community is of utmost importance. Family and family members are linked with the community and society in many ways of participating in working life and school and free time recreation. The relationships with relatives and friends may provide social support during the crises or in everyday life by providing warmth, care, and help. Resilience factors are in the relationship with the community as access to social networks, but also in safe neighborhoods, access to childcare and education, medical care, and getting supportive mentors and peer-relationships for a child and the parents [85]. The relationships between a family and the community may be reciprocal and offer flexible participation and support when needed. The family can also be isolated for reasons of moving far away from relatives and friends, or for some other reason causing withdrawal. Sometimes this phenomenon may be interpreted by the child welfare system as hard to help or as hard to reach families [86].

The changes in family structures and the increasing vulnerability of families mean that we have to focus on both: the resilience factors inside the family, but also more on the families as part of their communities. For example, the current COVID-19 pandemic has revealed the connections between families and schools and the workplaces and adult family members. There are also significant differences in communities concerning the social support, networks, family cultures, and the bonds with the society.

A social sustainability perspective allows us to focus more on sustainability issues in communities, not forgetting the economic and ecological dimensions with the principles of justice with inclusion and recognition, which may be a concern for the neighborhoods and whole communities. Community resilience has an essential role for families who live in a community. Community resilience is existence, development, and engagement of resources in the community used by community members to cope in a changing environment with uncertainty and unpredictability [28]. Hence, family resiliency interrelates reciprocally with community resiliency. The relationships between children, families, and community are established and sustained in institutions of daycare, schoolwork, non-governmental organizations, and leisure activities. Additionally, participatory democracy can create channels for people to participate and influence on society and local decision-making. A resilient society with a resilient community allows people natural, cultural, social, economic, political, and human resources to participate in the development of community and be active agents as community members [28]. 
Equal access to education is an essential part of social sustainability [9], and school may provide children with a channel to practice engagement in society and create a basis for lifelong social capital.

\section{Children's Rights and Societies' Responsibilities}

In this chapter, we will implicate the dimensions and levels of family and child welfare. By doing so, we provide a conceptual framework for sustainable family and child welfare. Before doing that, we will discuss socio-ethical perspectives on family and child welfare.

\subsection{Socio-Ethical Perspectives on Family and Child Welfare}

Consisting of policy processes aiming to promote children's welfare, including child- and family-specific aid for children at risk, child welfare policies deal with contextual, relational, and conditional social questions of the childhood, policies, and legislation concerning the child and family are key issues therein [87]. In this sense, child welfare in close connection to the philosophy of children's rights is ethically a complex domain concerning the relationship between family privacy and the power of public authority.

In the light of socio-ethical values, norms, and principles, child welfare is an ethical mission fulfilling certain moral ideas and principles. The modern child welfare is seen to be based on the idea of a responsible society in terms of normative social ethics obliging to carry out the principle of the best interest of the child. However, this concept is unclear [61], and children's rights can be interpreted differently with different consequences for children and parents, as well as professionals [41]. In general, child welfare is regarded as society's right and duty to promote children's wellbeing and protect children according to the need, including family interventions and taking the child into protective services, even against the parent's will.

In principle, national child welfare and family systems are based on the principle of the prior right and responsibility of parents to determine the care and upbringing of their children. Following the ideal of the "human family", modern societies have established a comprehensive family service system to ensure adequate parenting as a universal right like the right to education [18]. However, modern child welfare allows, and even obliges, public authorities in charge to not only support, but also to control and intervene in the case of inadequate parenting endangering the child's healthy development. Several justifications for family interventions have been given.

In ethical deduction, the justification for exercising public power in relation to family autonomy requires coordination and reconciliation of the rights of the child with parental rights and the interests of society. Although there may be mistrust in the system among citizens [88], it seems that there is a general sense of justice that not only accepts, but also demands such a normative regulation in the name of the best interest of the child [89]. This principle is in the best interest of the child and has been adopted widely in modern child law. The ethical argumentation is multidimensional with respect to the ideas of social justice, equality of opportunity, and public responsibility for social security.

\subsection{A Conceptual Framework for Socially Sustainable Family and Child Welfare}

In general, it is difficult to assert different perspectives on the justification for exercising public power in terms of family intervention. In any case, the following points can be mentioned concerning the right and duty of public authorities to intervene in family privacy when it pertains to protecting a child. Simultaneously, the rights and best interests of families and global actors are recognized. Table 1 summarizes the conceptual framework for socially sustainable family and child welfare. We have consisted the table by combining the perspectives of values and practices, interdependence, and resiliency (presented in Figure 1), and condensed the core dimensions and goals in child, family, society, and global levels. 
Table 1. A conceptual framework for socially sustainable family and child welfare.

\begin{tabular}{|c|c|c|c|}
\hline & Values \& Practices & Interdependence & Resiliency \\
\hline Child & $\begin{array}{l}\text { Children as the most important } \\
\text { resource of society (human capital) } \\
\text { The right of the child for protection } \\
\text { (children's rights, the best interest of } \\
\text { the child) }\end{array}$ & $\begin{array}{l}\text { Accordance with the idea } \\
\text { of human dignity of the } \\
\text { child (universal } \\
\text { moral norm) }\end{array}$ & $\begin{array}{l}\text { Promotion of happiness, } \\
\text { wellbeing, security, } \\
\text { and quality of life of } \\
\text { children (prosperity) }\end{array}$ \\
\hline Family & $\begin{array}{l}\text { The right of the family for getting } \\
\text { support by society (parent's rights, } \\
\text { the best interest of parents) }\end{array}$ & $\begin{array}{l}\text { Considerable complexity } \\
\text { of parenting in modern } \\
\text { society (modernization) }\end{array}$ & $\begin{array}{l}\text { Promotion of happiness, } \\
\text { wellbeing, security, } \\
\text { and quality of life of } \\
\text { families (prosperity) }\end{array}$ \\
\hline Society & $\begin{array}{l}\text { Traditionally human societies have } \\
\text { attended to offspring (tradition) } \\
\text { Law-based requirement (legal norm) } \\
\text { The right of society for maintaining } \\
\text { socialization, morality, security, } \\
\text { and civil peace (the best interest } \\
\text { of society) }\end{array}$ & $\begin{array}{l}\text { Consistent with benefit } \\
\text { of society (social utility) } \\
\text { Total utility } \\
\text { (greatest good) }\end{array}$ & $\begin{array}{l}\text { Acceptable and desirable } \\
\text { in all civilized } \\
\text { rule-of-law societies } \\
\text { (historical sophistication) }\end{array}$ \\
\hline Global & $\begin{array}{l}\text { Matching with public opinion and } \\
\text { citizens' sense of justice with respect } \\
\text { to social, economic, } \\
\text { and environmental sustainability } \\
\text { (universal acceptance/justice) }\end{array}$ & $\begin{array}{l}\text { Interaction between } \\
\text { social, economic, } \\
\text { and environmental } \\
\text { sustainability (universal } \\
\text { collaboration/systems) }\end{array}$ & $\begin{array}{l}\text { Consistent with social, } \\
\text { economic, } \\
\text { and environmental } \\
\text { sustainability (universal } \\
\text { functionality/ } \\
\text { survival, thrive) }\end{array}$ \\
\hline
\end{tabular}

In the first row in Table 1, child rights are the basic premise that relates human rights and human dignity with the universal moral norm of human dignity of the child. The purpose of socially sustainable family and child welfare is to protect prosperity of all children by promoting their happiness, wellbeing, and security.

The second row in Table 1 refers to families, which are the main growth environment in children's lives. In child welfare, sustainable family life, including promotion of happiness, wellbeing, security, and quality of life of family members, is essential for children's wellbeing. However, modernization affects families' lives, providing both opportunities and challenges such as digitalization and climate change. Therefore, families have not only a responsibility to support their children's growth in changing circumstances in a modern society but also a right to receive support from society to thrive.

On a societal level, the support for children and families is rooted in the tradition of how families are supported by society, legislation, and family policy, as well as child protection practices and regulation on how a society can intervene into private family life. There needs to be a balance between the best interests of societies as a whole and those of their individuals, i.e., families and children. Societies' best interests here are socialization, morality, security, and civil peace, as well as protection of children as population group. The historical perspective provides a lens to scrutinize and support the resilience of societies.

Finally, national and international levels of the framework are crucial in putting sustainable development and children's rights into practice in versatile countries. Social sustainability is considered together with economic and environmental sustainability to provide a full image of sustainable family and child welfare. In practice, it requires universal acceptance of justice, interaction, and collaboration as well as universal functionality to survive and, preferably, to flourish as a society.

The points made in the Table 1 are partly collateral, partly complete each other, and some are partly subordinate to other, higher aspects. Each argument might be regarded as somehow justifiable, although theoretically, in different ways. In general, it is possible to justify family intervention by invoking the intention (beneficial aspiration), obligating norm (responsibility), or consequences (social impact). In each of these, the implication of the concept of the best interest of the child is different. 
From the perspective of sustainable development, the argument may primarily refer to beneficial social consequences. The framework is based on the notion that all levels (i.e., child, family, society, and global) need to be considered in implementing sustainable family and child welfare.

In modern society, rational risk limitation is a crucial element of policymaking, which has directed attention from the idea of natural human rights increasingly to the possible benefits of certain measures for society including field child welfare policy [90]. As estimation of the consequences of decisions is undoubtedly subject to policymaking, it is an integral part of case-specific child protection, including modelling of professional standards [91,92]. In research on child protection systems and child and family policy promoting social sustainability, it is important to consider the global diversity of national systems. The various contexts of developing and developed countries and regions need to be considered in combining sustainability development goals with children's rights [93].

Furthermore, there is tension between the idea of universal rights of the child and the consequentialist rationalization of the child welfare. One of the challenges is how to implement and evaluate children's rights from a policy perspective and set them into broader framework of social sustainability. Vast cultural and policy changes need to be made in recognizing and promoting the children's status as members of society [94] alongside protection, participation, and provision.

Economic, environmental, and social sustainability provide a cross-sectional theme in the conceptual framework. In the context of family and child welfare, economic sustainability is related to financial and structural support for families, such as child-related financial transfers [44] and early childhood education and care [45]. These support the sufficiency of family income [94]. Environmental sustainability refers to the local or global functions and collaboration in changing circumstances where children are the most vulnerable group of people [78]. Social sustainability, however, ultimately refers to recognizing the children's rights. In Daly's [94] classification of social policy approaches to children, the highest goal is to treat children as subjects, and empowerment is seen as an ambition [94]. This type of approach focuses on both children and adults that are also in the center of the framework.

There are two main schools of ethical theory-deontological and utilitarian-which provide two basic perspectives on the ethical justification of family interventions. The deontological justification invokes universal moral law, commanding us to protect children unconditionally, even against parental will if need be, while the utilitarian justification is based on a consequentialist calculation of utility. According to the deontological point of view, moral duty is not founded on empiric knowledge, but should be defined by reason. This is to say that children must be protected regardless of potential profits for society.

However, there is empiric evidence of the utility of a functional system of family intervention such as diminution of criminality, mental problems, and substance abuse in the long run. Child welfare policies and the systems of family interventions and substitute care might be advocated by referring to the beneficial consequences, economic or social, instead of and alongside the right of the child. Accordingly, supporting economic and environmental sustainability can and should be used to support prosperity of children and families in a resilient way. A conceptual framework provides, therefore, a systemic entity that can be used to demonstrate the interconnectedness of the stakeholders and elements in sustainable family and child welfare. The framework acts as a starting point in developing conceptual clarification in the field of social sustainability, and the authors encourage the readers to develop the concepts further.

\section{Conclusions}

In this paper, we have presented how family and child welfare are understood from the viewpoint of social sustainability. By doing so, we demonstrated that child welfare is an essential element of sustainable social development, even sustainable development in general. The article provided a multi-layered, multifaceted entity of values and practices, interdependence, and resiliency within children, families, societies, and on a global scale. The sustainable aspect of the framework emphasizes the interdependence of various stakeholders in children, families, societies, and the world. The challenge 
is how to balance and equate the implementation of children's rights as well as family and child welfare on all levels and in different circumstances.

The idea of child welfare provides a promise to citizens: society has committed to promote children's wellbeing and protect children at risk or in special need. This commitment is significantly rationalized by referring to the innate, human dignity of every individual child and any positive consequences in terms of social development. The promise itself provides a sense of security and confidence in the future as well as instantiates humanity and human values in a high sense of the word.

Today's rapid social change impacts significantly on micro-social circumstances. The preconditions of family life and lives of children are shaped by the change of societal structures worldwide including change of job life, educational requirements, digitalization of lifestyle, and other corresponding spheres of living. These changing processes have been barely discussed from the point of view of social sustainability.

It may be apparent that families play a crucial role in sustainable development by providing the mental foundation for appropriate social evolution. However, from an ethical point of view, it may be doubtful to subordinate child welfare to external social benefits instead of the dignity and individual rights of the child herself. We also need to acknowledge that provision of sustainable family and child welfare is not limited to individual societies; instead, we promote the understanding of the global responsibility to enhance child welfare and decrease inequality within families and amongst children.

Although the concept of sustainability has hardly been used in comparative research on family policy or child protection systems, it is clear that in different countries, supporting families and promoting children's wellbeing is generally seen as an important part of socially sustainable development. The ideology of children's rights as well as the concepts of child welfare and family support are easy to see as an integral part or even critical factors in the sustainable development agenda in terms of both goals and means. The connection with sustainable development is obvious, although not explicit so far.

This article provides a conceptual framework for socially sustainable family and child welfare. Our framework is one way to consider preconditions on protecting children without disregarding family life as an essential growth environment for a child. We emphasize in our framework the interconnectedness of the different levels of protecting children and families.

Our framework is one effort to include in the discussion on the UN's Sustainability Development Goals how they can be promoted from the perspective of children. By doing this, we complement the literature on sustainable development and children's rights $[3,5,6]$ from a family and child welfare viewpoint. To this end, we need to focus on different levels so that the global goals lead to sustainable family life and child welfare [3]. In this framework, we have addressed the importance of family as a core institution and one aspect to be considered in supporting the implementation of child's rights, development, education, and health. More research is needed for studying family and child welfare from a social sustainability viewpoint.

Author Contributions: Conceptualisation, writing, and editing J.H., K.P., and R.V. All authors have read and agreed to the published version of the manuscript.

Funding: This research received no external funding.

Conflicts of Interest: The authors declare no conflict of interest.

\section{References}

1. Léger, M.T.; Pruneau, D.A. Grounded Theory Perspective on Eco-Sustainable Change in Families. Ecopsychology 2013, 3, 237-247. [CrossRef]

2. United Nations. The Sustainable Development Goals Report 2016; Department of Economic and Social Affairs: New York, NY, USA, 2016. 
3. Bruckkauf, Z.; Cook, S. Child-Centred Approach to Sustainable Development Goals in High-Income Countries: Conceptual Issues and Monitoring Approaches; Innocenti Working Paper 2017-06; UNICEF: Florence, Italy, 2017. Available online: https://www.unicef-irc.org/publications/901-child-centred-approach-to-sdgs-inhigh-income-countries.html (accessed on 24 September 2020).

4. Silver, K.L.; Singer, P.A. A focus on child development. Editorial. Science 2014, 345, 121. [CrossRef] [PubMed]

5. Raikes, A.; Yoshikawa, H.; Britto, P.R.; Iruka, I. Children, Youth and Developmental Science in the 2015-2030 Global Sustainable Development Goals. Soc. Policy Rep. 2017, 30, 1-23. Available online: https://srcd. onlinelibrary.wiley.com/doi/abs/10.1002/j.2379-3988.2017.tb00088.x (accessed on 24 September 2020). [CrossRef]

6. Moyer, J.D.; Hedden, S. Are we on the right path to achieve the sustainable development goals? World Dev. 2020, 127, 1047-1049. [CrossRef]

7. Alfvén, T.; Dahlstrand, J.; Humphreys, D.; Helldén, D.; Hammarstrand, S.; Hollander, A.-C.; Målqvist, M.; Nejat, S.; Jørgensen, P.S.; Friberg, P.; et al. Placing children and adolescents at the centre of the Sustainable Development Goals will deliver for current and future generations. Glob. Health Action 2019, 12, 1670015. [CrossRef] [PubMed]

8. Mensah, J. Sustainable development: Meaning, history, principles, pillars, and implications for human action, Literature review. Cogent Soc. Sci. 2019, 5, 165353. [CrossRef]

9. Åhman, H. Social sustainability-society at the intersection of development and maintenance. Local Environ. 2013, 18, 1153-1166. [CrossRef]

10. Moody, Z. The United Nations Declaration of the Rights of the Child (1959): Genesis, transformation and dissemination of a treaty (re)constituting a transnational cause. Prospects 2015, 45, 15-29. [CrossRef]

11. United Nations. Convention on the Rights of the Child; UN General Assembly Resolution 44/25; Office of the United Nations High Commissioner for Human Rights: Geneva, Switzerland, 1989.

12. Geneva Declaration. Geneva Declaration of the Rights of the Child. 1924. Available online: http://cpd.org.rs/ wp-content/uploads/2017/11/01_-_Declaration_of_Geneva_1924.pdf (accessed on 11 August 2020).

13. United Nations. Declaration of the Rights of the Child, G.A. res. 1386 (XIV), 14 U.N. GAOR Supp. (No. 16) at 19, U.N. Doc. A/4354. 1959. Available online: http://hrlibrary.umn.edu/instree/k1drc.htm (accessed on 3 August 2020).

14. Stearns, P.N. History of Children's Rights. In Handbook of Children's Rights. Global and Multidisciplinary Perspectives; Ruck, M.D., Peterson-Badali, M., Freeman, M., Eds.; Routledge: New York, NY, USA, 2017; pp. 3-20.

15. UNICEF UK. What is the UNCRC? 2020. Available online: https://www.unicef.org.uk/what-we-do/unconvention-child-rights/ (accessed on 2 September 2020).

16. Bhardwaj, S.; Sambu, W.; Jamieson, L. Setting an Ambitious Agenda for Children: The Sustainable Development Goals; South African Child Gauge 2017; Children's Institute, University of Cape Town: Cape Town, South Africa, 2017.

17. European Commission. Evaluation of Legislation, Policy and Practice on Child Participation in the European Union (EU), Final Report. Directorate-General for Justice and Consumers (DG JUST), EUR 309; Publications Office of the European Union: Luxembourg, 2015. Available online: https://op.europa.eu/en/publication-detail/-/ publication/3f3c50b2-6a24-465e-b8d1-74dcac7f8c42/language-en/format-PDF (accessed on 10 August 2020).

18. Bergström, Y. The Universal Right in Education: Freedom, Equality and Fraternity. Stud. Philos. Educ. 2010, 29, 167-182. [CrossRef]

19. Todres, J. Children's Rights and Women's Rights: Interrelated and Interdependent. In Handbook of Children's Rights. Global and Multidisciplinary Perspectives; Ruck, M.D., Peterson-Badali, M., Freeman, M., Eds.; Routledge: New York, NY, USA, 2017; pp. 21-35.

20. Chernaya, A.V. Children's Rights Concept in Modern Social and Humanitarian Discourse. J. Soc. Stud. Educ. Res. 2018, 9, 140-167.

21. Ruiz-Casares, M.; Collins, T.M.; Tisdall, E.K.M.; Grover, S. Children's rights to participation and protection in international development and humanitarian interventions: Nurturing a dialogue. Int. J. Hum. Rights 2017, 21, 1-13. [CrossRef]

22. Harding, L.F. Perspectives in Child Care Policy, 2nd ed.; Routledge: London, UK, 1997. 
23. Gilbert, N.; Parton, N.; Skivenes, M. Child Protection Systems: International Trends and Orientations; Oxford University Press: New York, NY, USA, 2011.

24. Horwath, J. Child Neglect: Identification \& Assessment; Palgrave Macmillan: Basingstoke (Hampshire), UK, 2007.

25. Smith, M.R.; Fong, R. The Children of Neglect: When No One Cares; Brunner-Routledge: New York, NY, USA, 2004.

26. Hart, R. Children's Participation: The Theory and Practise of Involving Young Citizens in Community Development and Environmental Care; Earthscan: New York, NY, USA, 2007.

27. Sinclair, R. Participation in Practice: Making it meaningful, effective and sustainable. Child. Soc. 2004, 18, 106-118. [CrossRef]

28. Magis, K. Community resilience: An Indicator of social sustainability. Soc. Nat. Resour. 2010, 23, 401-416. [CrossRef]

29. Eizenberg, E.; Jabareen, Y. Social Sustainability: A New Conceptual Framework. Sustainability 2017, 9, 68. [CrossRef]

30. UNICEF. UNICEF Is the Custodian or Co-Custodian for 19 SDG Indicators. Available online: https: //data.unicef.org/children-sustainable-development-goals/ (accessed on 11 August 2020).

31. United Nations. Decade of Action to End Violence against Children. Available online: https: //violenceagainstchildren.un.org/content/2030-childrens-rights-agenda (accessed on 11 August 2020).

32. Unesco. Leading SDG 4-Education 2030. Available online: https://en.unesco.org/themes/education2030sdg4 (accessed on 11 August 2020).

33. Bronfenbrenner, U. The Ecology of Human Development: Experiments by Nature and Design; Harvard University Press: Cambridge, MA, USA, 1979.

34. Bernheimer, L.P.; Gallimore, R.; Weisner, T.S. Ecocultural Theory as a Context for the Individual Family Service Plan. J. Early Interv. 1989, 14, 219-233. [CrossRef]

35. Bers, M.U.; New, R.S.; Boudreau, L. Teaching and Learning when No One IS Expert: Children and Parents Explore Technology. Early Child. Res. Pract. 2004, 6, 2. Available online: http://ecrp.illinois.edu/v6n2/bers. html (accessed on 3 August 2020).

36. Montgomery, H. Anthropological Perspectives on Children's Rights. In Handbook of Children's Rights. Global and Multidisciplinary Perspectives; Ruck, M.D., Peterson-Badali, M., Freeman, M., Eds.; Routledge: New York, NY, USA, 2017; pp. 97-113.

37. Payne, L. Child Rights Impact Assessment as a policy improvement tool. Int. J. Hum. Rights 2019, 23, 408-424. [CrossRef]

38. Ben-Arieh, A.; Tarshish, N. Children's Rights and Well-being. In Handbook of Children's Rights. Global and Multidisciplinary Perspectives; Ruck, M.D., Peterson-Badali, M., Freeman, M., Eds.; Routledge: New York, NY, USA, 2017; pp. 68-79.

39. Clark, A.; Kjørholt, A.T.; Moss, P. (Eds.) Beyond Listening: Children's Perspectives on Early Childhood Services; University Press: Bristol, UK, 2005.

40. Roos, P.; Rutanen, N. Metodologisia haasteita ja kysymyksiä lasten tutkimushaastattelussa [Methodological challenges and questions in children's research interview]. J. Early Child. Educ. Res. 2014, 3, $27-47$.

41. Aitken, S.C. Children's rights: A critical geographic perspective. In Routledge International Handbook of Children's Rights Studies; Vandenhole, W., Desmet, E., Reynaert, D., Lembrechts, S., Eds.; Routledge: Abingdon, UK, 2015; pp. 131-146.

42. Mayall, B. Children's rights and the sociology of childhood. In Routledge International Handbook of Children's Rights Studies; Vandenhole, W., Desmet, E., Reynaert, D., Lembrechts, S., Eds.; Routledge: Abingdon, UK, 2015; pp. 77-93.

43. Saraceno, C. Family Policies, Concepts, Goals and Instruments; Carlo Alberto Notebooks, No. 230; Collegio Carlo Alberto: Torino, Italy, 2011.

44. Kamerman, S.; Kahn, A.J. (Eds.) Family Policy: Government and Families in Fourteen Countries; Columbia University Press: New York, NY, USA, 1978.

45. Daly, M.; Ferragina, E. Family policy in high-income countries: Five decades of development. J. Eur. Soc. Policy 2018, 28, 255-270. [CrossRef]

46. Gillies, V. Meeting parents' needs? Discourses of 'support' and 'inclusion' in family policy. Crit. Soc. Policy 2005, 25, 70-90. [CrossRef] 
47. Houston, S.; Dolan, P. Conceptualising Child and Family Support: The Contribution of Honneth's Critical Theory of Recognition. Child. Soc. 2008, 22, 458-469. [CrossRef]

48. Kilkelly, U. The Best of Both Worlds for Children's Rights? Interpreting the European Convention on Human Rights in the Light of the UN Convention on the Rights of the Child. Hum. Rights Q. 2001, 23, 308-326. [CrossRef]

49. United Nations. The Universal Declaration of Human Rights; UN General Assembly: New York, NY, USA, 1948.

50. UNCRC. Convention on the Rights of the Child. 1989. Available online: https://www.ohchr.org/documents/ professionalinterest/crc.pdf (accessed on 3 August 2020).

51. Herczog, M.; Krappman, L.; Cook, P. The new UN CRC General Comment 13: “The right of the child to freedom from all forms of violence"-Changing how the world conceptualises child protection. Child Abus. Negl. 2011, 35, 979-989.

52. Stalker, K.; McArthur, K. Child abuse, child protection and disabled children: A review of recent research. Child Abus. Rev. 2012, 21, 24-40. [CrossRef]

53. Brown, S.E.; Guralnick, M.J. International Human Rights to Early Intervention for Infants and Young Children with Disabilities. Tools for Global Advocacy. Infants Young Child. 2012, 25, 270-285. [CrossRef]

54. Engwall, K.; Östberg, F.; Andersson, G.; Bons, T.; Bringlöv, Å. Children with disabilities in Swedish child welfare-A differentiating and disabling practice. Eur. J. Soc. Work 2019, 22, 1025-1037. [CrossRef]

55. United Nations. Convention on the Rights of Persons with Disabilities-Articles. Available online: https://www.un.org/development/desa/disabilities/convention-on-the-rights-of-persons-withdisabilities/convention-on-the-rights-of-persons-with-disabilities-2.html (accessed on 3 August 2020).

56. Garbarino, J.; Briggs, A. An approach to assessing 'accountability' in implementing the UN Convention on the Rights of the Child: Implications for School Psychology. Sch. Psychol. Int. 2014, 35, 29-35. [CrossRef]

57. Woods, K.; Bond, C. Linking regulation of practitioner school psychology and the United Nations Convention on the Rights of the Child: The need to build a bridge. Sch. Psychol. Int. 2014, 35, 67-84. [CrossRef]

58. Nastasi, B.K.; Naser, S. Child rights as a framework for advancing professional standards for practice, ethics, and professional development in school psychology. Sch. Psychol. Int. 2014, 35, 36-49. [CrossRef]

59. Fiorvanti, C.M.; Brassard, M.R. Advancing Child Protection through Respecting Children's Rights: A Shifting Emphasis for School Psychology. Sch. Psychol. Rev. 2014, 43, 349-366. [CrossRef]

60. Xu, J.; Kosher, H.; Ben-Arieh, A.; Huebner, E.S. Children's Rights, School Psychology, and Well-Being Assessment. Soc. Indic. Res. 2014, 117, 179-193.

61. Wihstutz, A. Working vulnerability: Agency of caring children and children's rights. Childhood 2011, 18, 447-459. [CrossRef]

62. Smyers, P. Child Rearing in the "Risk" Society: On the Discourse of Rights and the "Best Interest of a Child". Educ. Theory 2010, 60, 271-284. [CrossRef] [PubMed]

63. Michie, J. (Ed.) The Handbook of Globalisation, 3rd ed.; Edward Elgar Publishing: Cheltenham, UK, 2019.

64. Steger, M.B.; Battersby, P.; Siracusa, J.M. (Eds.) The SAGE Handbook of Globalization; SAGE Publications: London, UK; Thousand Oaks, CA, USA; New Delhi, India; Singapore, 2014.

65. Turner, B.S.; Holton, R.J. (Eds.) The Routledge International Handbook of Globalization Studies, 2nd ed.; Routledge: Oxon, UK; New York, NY, USA, 2016.

66. McGovan, B.G. An Historical Perspective on Child Welfare. In From Child Welfare to Child Well-Being: An International Perspective on Knowledge in the Service of Policy Making; Kamerman, S.B., Phipps, S., Ben-Arieh, A., Eds.; Springer: Dordrecht, The Netherlands; Berlin/Heidelberg, Germany; London, UK; New York, NY, USA, 2010; pp. 25-48.

67. Montgomery, H. Children's Rights. In Oxford Bibliographies Online in Childhood Studies; Montgomery, H., Ed.; Oxford University Press: New York, NY, USA, 2015.

68. Buck, T. International Child Law, 3rd ed.; Routledge: London, UK; New York, NY, USA, 2014.

69. Gatenio Gabel, S. The Development of International Comparative Child and Family Policies. In From Child Welfare to Child Well-Being: An International Perspective on Knowledge in the Service of Policy Making; Kamerman, S.B., Phipps, S., Ben-Arieh, A., Eds.; Springer: Dordrecht, The Netherlands; Berlin/Heidelberg, Germany; London, UK; New York, NY, USA, 2010; pp. 175-188. 
70. Bruyre, E.; Garbarino, J. The Ecological Perspective on the Human Rights of Children. In From Child Welfare to Child Well-Being: An International Perspective on Knowledge in the Service of Policy Making; Kamerman, S.B., Phipps, S., Ben-Arieh, A., Eds.; Springer: Dordrecht, The Netherlands; Berlin/Heidelberg, Germany; London, UK; New York, NY, USA, 2010; pp. 137-154.

71. Lundy, L. Children's rights and educational policy in Europe: The implementation of the United Nations Convention on the Rights of the Child. Oxf. Rev. Educ. 2012, 38, 393-411. [CrossRef]

72. Hämäläinen, J.; Matikainen, P. Mechanisms and Pedagogical Counterforces of Young People's Social Exclusion: Some Remarks of the Requisites of Social Sustainability. Sustainability 2018, 10, 2166. [CrossRef]

73. Reynaert, D.; Roose, R. Children's Rights: A Framework to Eliminate Social Exclusion? Critical Discussions and Tensions. In Handbook of Children's Rights. Global and Multidisciplinary Perspectives; Ruck, M.D., Peterson-Badali, M., Freeman, M., Eds.; Routledge: New York, NY, USA, 2017; pp. 36-52.

74. Khadka, S. Social rights and the United Nations Child Rights Convention (UN-CRC): Is the CRC a help or hindrance for developing universal and egalitarian social policies for children's wellbeing in the 'developing world'? Int. J. Child. Rights 2013, 21, 616-628. [CrossRef]

75. Dolan, P.; Zegrac, N.; Arsic, J. Family Support as a right of the child. Soc. Work Soc. Sci. Rev. 2019, 21, 8-26. [CrossRef]

76. Ferragina, E. The political economy of family policy expansion. Rev. Int. Political Econ. 2019, 26, 1238-1265. [CrossRef]

77. Ferragina, E. Family policy and women's employment outcomes in 45 high-income countries: A systematic qualitative review of 238 comparative and national studies. Soc. Policy Adm. 2020, 1-51. [CrossRef]

78. McKinney, S. The relationship of child poverty to school education. Improv. Sch. 2014, 17, 203-216. [CrossRef]

79. Anderko, L.; Chalupka, S.; Du, M.; Hauptman, M. Climate changes reproductive and children's health: A review of risks, exposures, and impacts. Pediatr. Res. 2020, 87, 414-419. [CrossRef] [PubMed]

80. Creel, L. Children's Environmental Health: Risks and Remedies; PRB, Making the Link; Population Reference Bureau: Washington, DC, USA, 2002.

81. Mitchell, P.; Borchard, C. Mainstreaming children's vulnerabilities and capacities into community-based adaptation to enhance impact. Clim. Dev. 2014, 6, 372-381. [CrossRef]

82. Taimalu, M.; Lahikainen, A.R.; Korhonen, P.; Kraav, I. Self-reported fears as indicators of young children's wellbeing in societal change: A cross-cultural perspective. Soc. Indic. Res. 2007, 80, 51-78. [CrossRef]

83. Walsh, F. Family resilience: A framework for clinical practice. Fam. Process 2003, 42, 1-18. [CrossRef]

84. Patterson, J.M. Understanding Family Resilience. J. Clin. Psychol. 2002, 58, 233-246. [CrossRef]

85. Black, K.; Lobo, M.A. Conceptual Review of Family Resilience Factors. J. Fam. Nurs. 2008, 14, 33-55. [CrossRef]

86. Benzies, K.; Mychasiuk, R. Fostering family resilience. Child Fam. Soc. Work 2009, 14, 103-114. [CrossRef]

87. Boag-Munroe, G.; Evangelou, M. From hard to reach to how to reach: A systematic review of the literature on hard-to-reach families. Res. Pap. Educ. 2012, 27, 209-239. [CrossRef]

88. Roose, R.; Bouverne-De Bie, M. Do Children Have Rights or Do Their Rights Have to be Realised? The United Nations Convention on the Rights of the Child as a Frame of Reference for Pedagogical Action. J. Philos. Educ. 2007, 41, 431-443. [CrossRef]

89. Juhasz, I.; Skivenes, M. The Population Confidence in the Child Protection System-A Survey Study of England, Finland, Norway and the United States (California). Soc. Policy Adm. 2017, 51, 1330-1347. [CrossRef]

90. Gjerdstad, E.; Kotikasvatuksessa, V. [Power in Domestic Upbringing]; Kasvatustieteen laitoksen julkaisuja 225; University of Helsinki: Helsinki, Finland, 2009.

91. Parton, N. Risk, Advanced Liberalism and Child Welfare: The Need to Rediscover Uncertainty and Ambiguity. Br. J. Soc. Work 1998, 28, 5-27. [CrossRef]

92. Munro, E. Effective Child Protection; SAGE Publications: London, UK, 2002. 
93. Johnson, A.K.; Sloth-Nielsen, J. Safeguarding Children in the Developing World-Beyond Intra-Organisational Policy and Self-Regulation. In Critical Debates and Developments in Child Protection; Parton, N., Ed.; MDPI: Basel, Switzerland; Beijing, China; Wuhan, China; Barcelona, Spain; Belgrade, Serbia; Manchester, UK; Tokyo, Japan; Cluj, Romania; Tianjin, China, 2020; pp. 127-145.

94. Daly, M. Children and their Rights and Entitlements in EU Welfare States. J. Soc. Policy 2019, 49, 343-360. [CrossRef]

Publisher's Note: MDPI stays neutral with regard to jurisdictional claims in published maps and institutional affiliations.

(C) 2020 by the authors. Licensee MDPI, Basel, Switzerland. This article is an open access article distributed under the terms and conditions of the Creative Commons Attribution (CC BY) license (http://creativecommons.org/licenses/by/4.0/). 